\title{
AN EMPIRICAL INVESTIGATION OF FACTORS AFFECTING ENTREPRENEURIAL CAPABILITY (EC) ENVIRONMENT IN ASEAN-5 ECONOMIES
}

\author{
Munshi Naser Ibne Afzal' ${ }^{1,2}$, Shamim Ahmad Siddiqui ${ }^{3}$, Kasim bin Hj. Md. \\ Mansur ${ }^{1}$, and Rini Suryati Sulong ${ }^{1}$ \\ ${ }^{I}$ Faculty of Business, Economics and Accountancy, Universiti Malaysia Sabah, \\ Jalan UMS, 88400 Kota Kinabalu, Sabah, Malaysia \\ ${ }^{2}$ Department of Economics, Shahjalal University of Science \& Technology, \\ Sylhet, Bangladesh \\ ${ }^{3}$ School of Business and Quality Management, Hamdan Bin Mohammed Smart \\ Univerity (HBMSU), Dubai, UAE \\ *Corresponding author: munshi.naser@gmail.com; munshi.naser@ums.edu.my
}

Published online: 21 December 2018

To cite this article: Afzal, M.N.I., Siddiqui, S.A., Mansur, K.M., and Sulong, R.S. (2018). An empirical investigation of factors affecting entrepreneurial capability (EC) environment in ASEAN-5 economies. Asian Academy of Management Journal, 23(2), 25-44. https://doi.org/10.21315/aamj2018.23.2.2

To link to this article: https://doi.org/10.21315/aamj2018.23.2.2

\begin{abstract}
The entrepreneurial capability (EC) environment of a given local or regional system refers to a set of social and economic factors that exert influence on entrepreneurial processes occurring within said system. To this end, the goal of the currently presented work is to determine and empirically validate the said EC factors in relation to the entrepreneurial environments of the Association of South East Asian Nations (ASEAN)-5, namely Indonesia, Thailand, Singapore, Malaysia, and the Philippines, both at the regional and national levels. For this purpose, the presented research adapted the entrepreneurial perceived capabilities framework to first investigate the key determinants of EC that affect key entrepreneurial processes, such as the seeking of new opportunities and the decision to venture into new commercial opportunities, within the context of ASEAN-5 economies. Next, the identified variables were empirically tested via an examination of their coefficients in relation to their impact on entrepreneurial perceived capabilities. Succinctly, the current work applied recent consistent estimation of panel bootstrap random-effects model to determine time variant changes with respect to the studied variables in the panel sample. The data used in the current work was obtained from the Global Entrepreneurship
\end{abstract}

(C) Asian Academy of Management and Penerbit Universiti Sains Malaysia, 2018. This work is licensed under the terms of the Creative Commons Attribution (CC BY) (http://creativecommons. org/licenses/by/4.0/). 
Monitor (GEM) and World Competitiveness Yearbook (WCY) databases for the years 2010-2016. The results of the current work suggest that factors such as beliefs regarding entrepreneurship as a good career choice (EnGC) and perceived opportunities (PO) yield significant positive impact on the efficiency of EC in ASEAN-5, and can be nurtured to further improve EC environments both at the regional and national levels. Conversely, the fear of failure (FefRa) variable was shown to exert considerable negative impact on the efficiency of ASEAN-5 EC environments. Variables such as intellectual property rights $(I P R)$, university education (UE), and knowledge transfer rate (KT) were also shown to have a positive impact on both national and regional ASEAN-5 EC environments. The current work thus makes a valuable contribution to the associated literature by presenting a robust empirical analysis of EC factors of ASEAN-5 economies, the results of which can be used to inform policies aimed at strengthening the EC settings of ASEAN-5 with respect to their pursuit of an innovation-driven region.

Keywords: ASEAN-5, entrepreneurial capability, Panel Bootstrap (PB) analysis, random effect model, entrepreneurial environment

\section{INTRODUCTION}

Incontestably, sufficient understanding of antecedent factors influencing the entrepreneurial process, whereupon potential entrepreneurs deem themselves equipped with sufficient entrepreneurial capabilities so as to make the leap from intention to entrepreneurship, can largely contribute to the development of efficient prediction models regarding entrepreneurship, as well as help inform policies aimed at increased entrepreneurship. To this end, entrepreneurial research to date has mainly focused on unveiling the direct effects of perceived capability, perceived opportunity, and fear of failure on entrepreneurial intention (Noguera, Alvarez, \& Urbano, 2013; Walker, Jeger, \& Kopecki, 2013), largely overlooking significant antecedents such as existing entrepreneurship opportunities, knowledge transfer rate, and the quality of the national tertiary education system. Using a bootstrap panel model to better explicate the relationships among these factors, the current work attempts to better elucidate the impact of the above understudied factors on entrepreneurial capability (EC), namely entrepreneurship opportunities, knowledge transfer rate, and quality of tertiary education, while also broadening our current understanding of the roles of perceived opportunity, fear of failure, and entrepreneurship opportunities on entrepreneurial capabilities. Likewise, as past literature has largely focused on unveiling entrepreneurial intention differences with respect to entrepreneurial self-efficacy and perceived opportunities (Haus, Steinmetz, Isidor, \& Kabst, 2013; Wilson, Kickul, \& Marlino, 2007), the current study enriches the existing entrepreneurial cognition literature by examining the moderating role of knowledge, innovation, and quality of national university 
education systems in the development of regional/national innovation systems using entrepreneurial capabilities. In the current work, we argue that entrepreneurial environment factors such as perceived capability, entrepreneurial opportunities, and fear of failure rate are contingent on the quality of national innovation strategies aimed at addressing knowledge transfer rates and the standard of tertiary education system. The main objective of the current research is thus to empirically investigate the impact of the above listed factors on the capacity of entrepreneurs to identify and exploit entrepreneurial opportunities for the greater mass of ASEAN-5 (namely Indonesia, Thailand, Singapore, Malaysia, and the Philippines) economies. To do so, the current work uses a moderated panel data approach that utilises bootstrap procedures to investigate the impact of the above listed factors, yielding robust results with respect to our objective. Further, the current work tests the empirically identified factors via the consistent estimation of Panel Bootstrap (PB) technique with respect to their significance as variables in the Perceived Entrepreneurial Capability Framework (Chen, Schmidt, \& Wang, 2014).

The development of the concept of EC has been recently supported by studies which have endeavoured to apply EC in a theoretical setting (Cantu-Ortiz, Galeano, Mora-Castro, \& Fangmeyer, 2017; Tofighi, Teymourzadeh, \& Ghanizadeh, 2017). In this regard, a great number of studies have aimed to elucidate the existent relationships among various EC factors at the individual level through investigations that consider the perspective of potential entrepreneurs who are part of the tertiary education system, such as students, staff, and faculty (Miranda, Chamorro-Mera, \& Rubio, 2017). Yet, most of these studies have investigated entrepreneurial intention, rather than the factors that affect the perceived capabilities of entrepreneurship (Siegel \& Wright, 2015). Succinctly, EC denotes the various capabilities that are necessary for potential entrepreneurs to use their skill and knowledge to identify, categorise, and exploit entrepreneurial opportunities in the university-industry-government domain (Nazaryeva, 2015; Šebjan, Tominc, \& Boršič, 2016; Nyström, 2008). Indeed, such studies, aimed at identifying and elucidating entrepreneurial capabilities with respect to the university-industrygovernment domain, have predominated the associated literature in recent years (Afzal, Mansur, \& Sulong, 2017; Antonioli, Nicolli, Ramaciotti, \& Rizzo, 2016).

Yet, cross-country and regional perspectives with respect to this topic remain largely understudied (Šebjan et al., 2016); indeed, as most work has been focused on the micro or individual level, there is an evident gap in the literature with respect to EC factors at the regional and cross-country levels. To date, little attention has been paid to the identification and empirical testing of key attributes of EC skill and the start-up dimension at the cross-country level (Hallam, Novick, Gilbert, Frankwick, \& Zanella, 2017), with very limited research carried out to account for EC at the 
national level (D'este, Mahdi, \& Neely, 2009). The present study endeavours to advance our current understanding of EC at the cross-country and regional levels by investigating EC factors pertaining to five countries in the Association of South East Asian Nations (ASEAN) region, namely Indonesia, Malaysia, the Philippines, Singapore, and Thailand, or, as they are commonly referred to, ASEAN-5. While quite different in terms of culture, history, and income per capita, these five countries have joined together in the pursuit of an innovation-driven ASEAN region, which necessitates the establishment of common regional economic policies aimed at this goal (Scippacercola, \& D’Ambra, 2014; Rashed, Deluyi, \& Daud, 2015).

As part of their economic development missions, many countries, including ASEAN-5, have focused on the development and implementation of strategies aimed at the growth and sustainability of national and regional EC environments. However, as emphasised by many entrepreneurship researchers, further theoretical and empirical research on EC is needed to help guide future research, as well as improve the consistency and relevance of regional and national economic strategies aimed at EC environment development (Bergmann, Mueller, \& Schrettle, 2014). To this end, use of global entrepreneurship data can help further our understanding of the existing relationships between EC and its determinants. As a practical implication, the findings of the current work can help inform future policies aimed at stimulating regional and national EC environments in the ASEAN region by delineating the most significant factors impacting the EC of individual countries as well as the region as a whole. The implementation of such policies, in turn, is expected to strengthen university-industry-government linkages, and aid in the creation of new employment opportunities for a new generation of entrepreneurs.

\section{EC WORKING FRAMEWORK}

While other frameworks, such as the resource-based framework and the entrepreneurial intention framework (Giuri, Grimaldi, \& Villani, 2014) have been proposed to explicate the entrepreneurial process, the current study followed the entrepreneurship perceived capability-based framework. Resources and capabilities represent two distinct sets of factors that may affect entrepreneurship. In this regard, the resource-based opinion emphasises the supply and access to resources, whilst the capability-based framework has as its focal point the skill and agency of the entrepreneur (Audu, Otitolaiye, \& Ibitoye, 2013).

While only few studies to date have adopted the capability-based framework, many researchers have suggested that the factors emphasised in the capability-based framework can better predict and explicate the processes that lead to innovation 
and the establishment of global business start-ups (Bergmann et al., 2014). Indeed, while the entrepreneurial perceived capability-based framework takes into account the supply of resources as well as the capabilities of the entrepreneur, it emphasises the procurement of opportunities to formulate start-ups via entrepreneur skill and knowledge (Siegel \& Wright, 2015). To this end, the capability-based framework is composed of three capability dimensions said to ease organisational spin-off, namely "opening new paths of action," "balancing organisational and commercial interests," and "integrating new resources" (Afzal, Mansur, \& Sulong, 2017). Opening new paths of action, in which the entrepreneur seeks to explore new business ideas within the entrepreneurship ecosystem, constitutes the first capability dimension of the framework. For example, patenting and licensing of new discoveries stemming from the university domain may reveal a new path of action towards entrepreneurship. In this regard, the likelihood of this process occurring is mostly dependent on the status of the university education system, the knowledge transfer rate between university and industry, and finally, the strength of a country's intellectual property rights (IPR) law (Woo, Jang, \& Kim, 2015). The capability dimension that concerns the balancing of organisational and commercial interests, in turn, pertains to the legitimisation of both organisational and commercial activities. For instance, the presence of active entrepreneurial incubation facilities may strike this balance, and thus foster spin offs. Finally, the third dimension, namely the capability to integrate new resources, relies on the entrepreneur's personal networking as well as the availability of entrepreneurship opportunities in the country. Moreover, past research has suggested that the degree to which potential entrepreneurs look for new entrepreneurial opportunities is related to individual and commonly-held national beliefs concerning entrepreneurship as a good career choice with respect to the national economic environment. The presence of positive attitudes regarding entrepreneurship certainly pushes forward potential entrepreneurs to capitalise on networks and resources globally (Light \& Dana, 2013). Thus, in this study, we have taken the aforementioned variables of the capability-based entrepreneurship framework into account for empirical analysis.

\section{SELECTION OF COUNTRIES}

ASEAN was formed in 1967 by Indonesia, Malaysia, the Philippines, Singapore, and Thailand to promote intergovernmental cooperation and facilitate economic, educational, military, political, and cultural integration amongst the member countries and Asian nations. Subsequently, the membership of the organisation has been expanded by the inclusion of Brunei, Cambodia, Laos, Myanmar, and Vietnam. The major aim of ASEAN concerns on acceleration of economic growth in the region. In 2015, the combined nominal gross domestic product (GDP) of 
ASEAN was more than US\$2,432 billion (ASEAN Secretariat, 2014; IMF, April 2016) after the USA, China, Japan, France, and Germany; ASEAN would thus represent the sixth largest economy in the world if it were a country. In this regard, with respect to their endeavours to uplift from efficiency- to technology-driven economies (Afzal \& Lawrey, 2014), ASEAN-5, namely the founder nations of ASEAN, possess a number of common economic and social attributes. For instance, the ASEAN Free Trade Area (AFTA) has been in operation since 1992 as a means to bring down intra-regional tariff charges. Likewise, with the exception of the Philippines, the governmental education expenditure of ASEAN-5 countries is around $20 \%$ of their total expenditure (ASEAN Secretariat, 2014). Similarly, apart from Indonesia, the primary export of ASEAN-5 countries is that of high-tech products (Capannelli, 2014), with the vast majority of such exports (in percentage) being integrated circuits (ICs) and computer data storage units (Simoes, Landry, Hidalgo, \& Teng, 2016). This ongoing trend certainly provides evidence of the strong technological advancement of the ASEAN-5 region. Indeed, the ASEAN Economic Community (AEC) aims to regionally establish technology-driven production advantages. However, in order to establish an economic region with a high level of competition, AEC measures will require the inclusion of competitionbased policies that advance national and regional innovation systems by nurturing their entrepreneurship capability environments.

As part of the larger 2025 ASEAN blueprint, the 2025 AEC blueprint aims to reduce economic gaps among ASEAN countries through the establishment of a highly integrated and cohesive economic region that is competitive, dynamic, and innovative. Uncontestably, the nurturing and sustainment of entrepreneurial activities in the region is necessary to accomplish this vision. Thus, as a means to achieve sustainable economic growth, AEC measures should accordingly seek to address the factors highlighted in the entrepreneurship capability-based model, as such factors play a vital role in the establishment and sustainment of the entrepreneurship process. Further, such policies should customise their focus to account for specific factors impacting EC frameworks at both national and regional levels.

\section{THEORETICAL BACKGROUND}

According to Schumpeter's (1942) entrepreneurship theory, within a given period, an entrepreneur has the opportunity to attempt an innovation using their skill and knowledge. If the entrepreneur succeeds, the innovation will create a more productive version of the product or process than previous versions. Specifically, 
the production of the intermediate good in use will increase last period's value, $A_{t-1}$, up to $A_{t}=\mathrm{g} A_{t-1}$, where $\mathrm{g}>1$. If the entrepreneur fails, then there will be no innovation at $t$, and the intermediate product will be the same one that was used in $t-1$; that is, $A_{t}=A_{t-1}$. In order to innovate, the entrepreneur must conduct research, a costly activity that uses the final good as its only input. However, as indicated above, the outcome of research is often uncertain, and may fail to generate any innovation. Generally speaking, however, the higher the expenditure on research, the more likely it is that it will lead to an innovation. Specifically, the probability $\mu_{\mathrm{t}}$ that an innovation occurs in any period $t$ depends positively on the amount $R_{t}$ of final good spent on research, according to the innovation function $\mu_{t}=\Omega\left(R_{t} / A_{t}{ }^{*}\right)$, where $A_{t}{ }^{*}=\Upsilon A_{t-1}$ is the productivity of the new intermediate product that will result if the undertaken research succeeds. The probability of innovation is here represented as inversely dependent on $A_{t}{ }^{*}$ since it is commonly established that as technology advances, it becomes more complex, and thus harder to improve upon. As such, it is not the absolute amount of research expenditure $R_{t}$ that predicts the likelihood of successful innovation, but the productivityadjusted expenditure $R_{t} / A_{t}{ }^{*}$, which we denote by $n_{t}$. Here, $n_{t}$ consists of factors that improve the productivity of innovation from the entrepreneur's perspective. In this paper, we have classified these as factors affecting the environment that enhances entrepreneurs' capabilities, productivity, and efficiency.

\section{LITERATURE REVIEW}

A significant amount of research has been carried out to better elucidate the various factors that compose the entrepreneurship capabilities domain. To this end, a series of approaches have been adopted to explicate entrepreneurship capabilities, encompassing for instance analyses of territorial aspects of entrepreneurship (Wright, 2007), comparative approaches aimed at determining geographical differences with respect to the entrepreneurial process (Klofsten \& Jones-Evans, 2000), and even assessments of the impact of individual and social factors on academic entrepreneurship (Clarysse, Tartari, \& Salter, 2011).

For instance, aiming to investigate the academic entrepreneurial environment of Iran, Tofighi et al. (2017) adopted a dynamic systems approach that utilised a non-probability version of cross-impact analysis (CIA) to investigate the behaviour of the entrepreneurial system within a medical university. In this study, researchers asserted that while the national entrepreneurial ecosystem continues to grow, structural measures are still needed to improve the current academic entrepreneurship environment. To this end, the authors recommended changes and 
improvements to a series of policy variables aimed at nurturing and sustaining the Iranian academic entrepreneurship environment, and further, presented a forecast of their potential impact on the proposed model.

In work by Rashed et al. (2015), the impact of transformational leadership behaviour on entrepreneurship was assessed via the developed two-step structural equation model (SEM) of entrepreneurship. This work, which adopted as research population among the staff of a public university in Iran, highlighted the enormous influence of the transformational leadership quality over entrepreneurial orientation.

Hallam et al. (2017), in turn, assessed the entrepreneurial ecosystem within the university domain via a multi-methodological study of the UT TRANSFORM Project (Translational Research Advancement Network to Support, Fund, Organize, Roll Out, and Motivate UT Innovations), a joint process carried out by four distinct University of Texas institutions. This study, which included application of the "Awareness Survey" to a statistically significant segment of the student, faculty, and staff of the university, revealed that a progressive entrepreneurial milieu plays a critical fostering role in the commercialisation of university-based technology.

In this regard, the capability-based entrepreneurship framework adapted in this study has been previously discussed and empirically studied through two distinct perspectives: one that seeks to analyse entrepreneurial capabilities at the institutional level, and one that has focus on the skill and knowledge of entrepreneurs at the individual level. In the context of cross-country and regional analyses, a few notable EC studies have been carried out to date. For instance, entrepreneurial intention has been studied at the cross-country level by Šebjan et al. (2016). This study, which included an analysis of entrepreneurial intention in eight countries in the Danube region, focused on assessing the impact of individual personality factors as well as demographic and human capital factors on entrepreneurial intention.

However, to the best of our knowledge, a macro-level empirical analysis of the capability-based entrepreneurship framework has yet to be reported in the literature. Indeed, very few studies have used econometric methods to explicate $\mathrm{EC}$ at the regional level, and fewer even have adopted the PB model in this effort. As such, the current study seeks to fulfill this existing gap in the literature, while further unveiling the impact of two main factors on EC that have gained much focus in recent years, namely entrepreneurial skills and opportunity-seeking abilities. To this end, the aforementioned studies have concluded that entrepreneurs have higher self-efficacy (Šebjan et al., 2016), risk tolerance, and willingness (Hallam et al., 2017) to establish start-ups, all qualities that are certainly related to the above factors. 


\section{DATA AND VARIABLE SELECTION}

This study considers one dependent variable and several independent variables. Empirical analysis of initial-stage entrepreneurship is often based on data available in the Global Entrepreneurship Monitor (GEM) research database. In addition to GEM 2016 data, the World Competitiveness Yearbook (WCY) 2016 research database is also utilised in the present study. Here, a PB data estimation method is utilised in the current work to test the relationship between entrepreneurial perceived capabilities, entrepreneurial internal skill factors, and external conditions on entrepreneurship. Our sample includes ASEAN-5 emerging market economies for the period of 2010-2016. The countries included in the sample are Indonesia, Malaysia, the Philippines, Singapore, and Thailand. As argued by Venkataraman (1997), entrepreneurs should possess the necessary skills and knowledge in the development of a new venture. To this end, Shane (2000) proposed that entrepreneurial skill is comprised of technological embodied knowledge. Thus, as the only dependent variable of the existing study, perceived capabilities of the entrepreneur (PerCa $)^{1}$ is taken into account in the current study. Fear of failure (FefRa), ${ }^{2}$ as an independent variable in this study, has been shown to exert great influence, generally negative, on entrepreneurial venture creation, and may indeed hinder entrepreneurs from fulfilling their potential (Arenius \& Minniti, 2005; Politis \& Gabrielsson, 2009). This study further considers as a variable the state of entrepreneurship as a good career choice (EnGC), ${ }^{3}$ a factor which is supported by several studies as an important explanatory variable in the entrepreneurial process (Davidsson, 1995; Krueger, 1993; Autio, Keeley, Klofsten, Parker, \& Hay, 2001). Perceived opportunity (PO), ${ }^{4}$ also accounted for in this study, comprises social and cultural comprehensions with respect to economic opportunities that enable a prediction of the productive chances of a firm (Druilhe, \& Garnsey, 2004; Penrose, 1959). Likewise, as the transformation of knowledge paves the way for innovation and consequently, entrepreneurial activities stemming from the innovation process (Afzal, 2013; Etzkowitz, Webster, Gebhardt, \& Terra, 2000), knowledge transfer $(\mathrm{KT})^{5}$ is considered as another independent variable in this study. Thomas and Carl (2001) argue that property rights play a critical role in the entrepreneurial process, as such laws provide support to entrepreneurs with regard to protecting their inventions, and thus aid in sustaining knowledge-based practices. As such, this study included Intellectual Property Rights (IPR) ${ }^{6}$ as an independent variable. Considering that the educational quality and standard of its universities and related tertiary institutions directly influence entrepreneurial activities in a given country, another independent variable, university education (UE), ${ }^{7}$ is introduced as a measurement of entrepreneurs' educational levels. This activity also helps to promote a competitive economy by fostering the development of young entrepreneurs at the tertiary level (Lockett \& Wright, 2005; Siegel, Waldman, Atwater, \& Link, 2003). 


\section{METHODOLOGY}

In the current work, model estimations are specified as follows:

$$
\begin{gathered}
\text { PerCait }=\alpha 0+\alpha 1 \text { POit }+\alpha 2 \text { FefRait }+\alpha 3 \text { EnGCit }+\alpha 4 \text { KTit } \\
+\alpha 5 \text { IPRit }+\alpha 6 \text { UEit }+ \\
\text { uit }=\mu i+\lambda t+v i t
\end{gathered}
$$

where $i$ denotes each emerging market economy studied in this work $(i=1,2$, $3, \ldots, 5)$, and $t$ represents the time period assessed $(t=2010-2016)$. Here, $\mu i$ represents the unobservable individual effect in Equation 2, $\lambda t$ corresponds to the unobservable time effect, and vit denotes the error term in Equation 2. Different from regular time-series or cross-section regressions, panel data regression offers a two-dimensional analysis approach: by combining both cross-section and timeseries regressions, panel data methodology enables enriched economic assessments via the enlargement of sample sizes and by allowing for data heterogeneity, which is supported via considerations of individual-specific variables. The random effect model operates under the assumptions that each individual unit intercept is random, and that constant intercepts and slopes of units and time, as well as those of individual differences, arise from the error term. Conversely, fixed-effect models assume constant errors and slopes in the units and time, thus allowing for investigations of intercept coefficients corresponding to unit and time. To this end, the Hausman specification test is often used as a tool to aid in the selection of the most suitable appropriate model for a given set of data between fixed-effect or random-effect models by comparing estimation coefficient vectors of said models. In this test, the fixed effect estimator is consistent under the null and alternative hypotheses, while the random effect estimator is efficient and consistent under the null hypothesis, but inconsistent under the alternative hypothesis. Thus, if the null hypothesis is accepted, then it can be assumed that individual specific effects are uncorrelated to any of the explanatory variables, thus implying that the randomeffect model provides a more appropriate model for a given application. In the current research, a Hausman test was carried out over the data, and a $p$-value below 0.05 was attained, indicating the random-effect model is a better fit for the data under analysis. In our study, the Hausman test followed the following format:

Test: Ho: difference in coefficients not systematic

$$
\begin{aligned}
\operatorname{chi} 2(0) & =(b-B)^{\prime}\left[\left(V_{-} b-V_{-} B\right)^{\wedge}(-1)\right](b-B) \\
& =0.00
\end{aligned}
$$


In recent years, panel data analysis has been widely used in a variety of fields, including statistics and econometrics (Xu \& Tian, 2017). Within this context, PB error component regression models are often used to analyse data from panel studies with random effects. For the sake of simplicity, the current work adapted a one-way error component regression model. Nevertheless, the main results reported in this article are also applicable in multiway error component regression models with complete panels.

Regarding the statistical method used in this work, the PB test was demonstrated as a flexible procedure capable of yielding satisfactory results irrespective of sample sizes or the values of the variance components. Indeed, practically speaking, the performance of the PB method can be said to be equivalent to that of the generalised inference model. Thus, the PB method is introduced in the current work as an alternative analysis method that affords a simple computation procedure and an easier-to-understand derivation workflow.

\section{RESULTS AND DISCUSSION}

As can be seen from the figures listed in Table 1, with the notable exception of FefRa, all studied variables yielded positive coefficients. Succinctly, the attained results suggest that the studied variables, namely the influence of role models, prior entrepreneurial experience, the perception of social support factors, as well as government policies related to IPR, are not being significantly nurtured so as to provide sufficient support to the EC in ASEAN-5 economies. For instance, the IPR variable, which yielded a positive yet insignificant coefficient, denotes that while IPR policies can yield a positive influence in EC, these are currently insufficiently implemented so as to significantly positively impact the studied EC environments. On the other hand, the results attained for the fear of failure variable, which yielded a negative coefficient, would indicate that EC performance and fear of failure hold an inverse relationship; as entrepreneurs feel increasingly burdened by a fear of failure, the less likely they are to apply their skills and knowledge in seeking new ventures in the economy. Such a finding certainly should be taken into account with respect to the development of policies directed at fostering the EC environment of ASEAN-5, which should certainly include measures to address this dimension of the entrepreneurial process. 
Table 1

Consistent PB estimation of random-effects model results

\begin{tabular}{lclcccc}
\hline \multicolumn{3}{c}{ Observed bootstrap } & \multicolumn{2}{c}{ Normal based } \\
\hline PerCa & Coef. & Std. Err. & $\mathrm{z}$ & $p>|\mathrm{z}|$ & \multicolumn{2}{c}{$[95 \%$ conf. interval] } \\
\hline PO & 0.2415374 & 0.3024083 & 0.80 & 0.424 & -0.351172 & 0.8342468 \\
FefRa & -0.7036952 & 0.3994804 & -1.76 & 0.078 & -1.486662 & 0.079272 \\
EnGC & 0.8360712 & 0.2715683 & 3.08 & 0.002 & 0.3038071 & 1.368335 \\
KT & 0.3318705 & 2.283505 & 0.15 & 0.884 & -4.143717 & 4.807458 \\
IPR & 3.07452 & 2.447704 & 1.26 & 0.209 & -7.871931 & 1.722891 \\
UE & 0.4271289 & 1.961961 & 0.22 & 0.828 & -3.418245 & 4.272503 \\
cons & 23.71474 & 30.96358 & 0.77 & 0.444 & -36.97276 & 84.40224 \\
\hline
\end{tabular}

As seen in Table 1, the impact of PO on output is positive and significant in the model. The results clearly show that factors affecting EC environments, such as EnGC, have a positive and significant impact on the determination of the production frontier. On the other hand, while positive, the coefficients for KT and UE are not significant in the PB model. This would imply that universities in ASEAN-5 are not sufficiently concentrating on promoting EC-based outcomes such as technology transfer, registration of new patents, the commercialisation of scientific inventions, and the establishment of licensing facilities. Such activities are vital for entrepreneurial capability development, as these constitute key external factors that influence the outcomes of EC activity, and that can thus improve the efficiency frontier of nations.

Our empirical findings certainly corroborate recent EC literature on ASEAN-5. For instance, a study on the relationship between an individual researcher's work environment and their engagement with entrepreneurship activity in Thailand shows that the commercialisation of academic entrepreneurs' research outputs plays an important role on social changes (Sooampon \& Igel, 2014). In that study, EC was defined as the experience of transforming scientific expertise into a commercial product or service to be sold in the market. While university-industry-government linkages were not shown as favourable to the EC environment in Thailand, public universities were shown to encourage entrepreneurial activities (Intarakumnerd \& Schiller, 2009).

On the other hand, the economy of Singapore is majorly dependent on industry and service entrepreneurship. To this end, measures taken by Singapore universities, as well as the implementation of appropriate government policies, have majorly contributed towards knowledge generation and commercialisation through entrepreneurship (Sohn \& Kenney, 2007). Indeed, the National University of 
Singapore has played a large entrepreneurial role in the national economy, fostering economic development through its various entrepreneurial activities (Wong, Ho, \& Singh, 2007).

Only three years into the Entrepreneurial University project, Malaysia's knowledge output has largely increased, as evidenced by the observed increases in the total numbers of scientific and technological publications as well as registered patents of Malaysian origin. Not only has there been an evidenced growth in the number of scientific publications, an increase in the total number of citations of works stemming from Malaysia has also been noted (Wong \& Goh, 2010; Razak \& Saad, 2007).

Indonesia and the Philippines, in turn, are catching up to their frontiers slowly but surely. At the moment, however, it can be asserted that ASEAN-5 countries are still burdened by a lack of sufficient government policies to support IPR laws, as well as the absence of regulation policies aimed at easing concerns related to taking entrepreneurial risks, and abating concerns regarding entrepreneurship as a good career choice. The results of the current study thus can be used to help guide ASEAN-5 policy makers in nurturing proper environments within individual countries, as well as within the region as a whole through increased efforts to further develop the capabilities listed above. Overall, the results of this work would seem to suggest that the panel estimates derived from the application of the PB model are relatively robust to the distributional assumptions that we made and have produced expected outcomes.

\section{Cross-Country Efficiency Differences}

A comparison of our findings with recent EC literature yields theoretical evidence to support our empirical results, particularly as it pertains to the importance of university education standards and knowledge transfer between the universityindustry domain as a means to develop skilled entrepreneurs. For example, taking into account the theory proposed by Aghion, Howitt, and Mayer-Foulkes (2005), let us assume two countries, namely Malaysia and Indonesia, have identical resource endowments. However, skilled entrepreneurs are found to be scarcer in Indonesia as opposed to Malaysia, an observation which we can denote as:

$$
H^{I} / L^{I}<H^{M} / L^{M}
$$

where $L$ and $H$ stand for the amounts of unskilled and skilled entrepreneurs employed in the technology-enhancing sector, respectively; and $I$ and $M$ represent the short form of Indonesia and Malaysia, respectively. Now, we assume that IPR 
law is not enforced in $I$, and that there is no trade between $I$ and $M$. Such would also imply that intermediate producers in $M$ cannot sell any goods which would need copyright protection to $I$. Thus, $M$ can only collect copyright rents from domestic innovators, while on the other hand, entrepreneurs in $I$ can imitate new technologies invented in $M$ at a small cost. This also discourages entrepreneurs in $I$ to innovate on their own. At one point, both countries will end up using the same technologies, and thus arrive at a steady-state of productivity in that region (assuming a two-country case). Entrepreneurs and inventors in either countries will have no incentive to further invent or commercialise inventions.

Therefore, numerically speaking,

$$
\frac{A_{H}}{A_{L}}=\frac{H}{L}
$$

where $A$ is the productivity parameter. Therefore, the establishment and implementation of appropriate government policies to support IPR laws are a crucial incentive for the region to innovate and remain competitive. The absence of such variables not only creates disincentive to entrepreneurs, it also contributes in creating cross-country efficiency differences. Thus, it can be concluded that in addition to university education standard and knowledge transfer rate, IPR laws comprise a significant external factor, that if sufficiently supported, can significantly enhance $\mathrm{EC}$ at the national or regional level.

\section{CONCLUSION AND CONTRIBUTION}

The current work introduced the PB model to estimate perceived EC assumed to affect the entrepreneurial environment of ASEAN-5 countries. To this end, accurate estimations of variables influencing the efficiency of EC at the national and regional levels can provide policy makers with feedback regarding current measures, as well as aid in the development and implementation of further measures aimed at improving the entrepreneurial ecosystem, thus contributing to the development of stronger innovation-driven economies.

The results of the current work have shown that the studied factors, namely perceived opportunities at the national level, attitudes regarding entrepreneurship as a good career choice, fear of failure, intellectual property rights, knowledge transfer rate, and national tertiary education standards, all exert significant influence on the entrepreneurial environment, and by extension, on national and regional production frontiers. Among the studied variables, perceived opportunities for entrepreneurship at the national level and attitudes regarding entrepreneurship as 
a good career choice were shown to be more influential variables on the quality of the EC environment in comparison to the degree of fear of failure experienced by entrepreneurs.

The results of our work have also demonstrated that variables such as knowledge transfer rate between the university-industry domain, as well as the standard of the tertiary education system in the country exert a positive influence on the EC of ASEAN-5 countries. Indeed, our findings indicate that these two factors may be the most important for future considerations regarding perfection of the production frontier. Overall, the methodology adapted in this work has been shown to provide an appropriate framework for evaluations of efficiency and determinations of coefficients of variables impacting EC environments at the national and regional levels.

Regarding the practical applications of the current research in view of strategic priorities for the ASEAN-5 region, several policy implications can be drawn out. In this regard, future changes to policies must take into account the key determinants affecting entrepreneurial decision-making processes, and thus include measures aimed at enhancing knowledge transfer rates, improving the quality of national tertiary education systems, as well as lessening the degree of fear experienced by potential entrepreneurs with respect to failure to successfully establish entrepreneurial businesses.

While past studies have contributed to the literature by examining differences in entrepreneurial intentions from cross-cultural and cross-country perspectives (e.g., Liñán \& Chen, 2009; Šebjan et al., 2016), delineating various factors affecting the EC of countries such as Taiwan, various countries in the Danube region, and Spain, the current study poses a reinstated definition of entrepreneurial capabilities. Further, the current work also demonstrates how the highlighted factors have contributed to shape the entrepreneurial processes in ASEAN-5 at both the regional and national levels via a stable PB analysis. Within this context, the current work extends our knowledge of EC environments of ASEAN-5 economies by filling gaps previously not addressed by notable entrepreneurial research carried out by Ramli and Senin (2015), Ismail, Nor, and Sidek (2015), Hamidon, Suhaimie, Mat Yunoh, and Hashim (2017), and Othman and Othman (2017).

As a future perspective, researchers should consider further work at the micro or individual level as a means to elucidate further sociocultural factors that shape the academic entrepreneurial environments of ASEAN-5 countries. Insufficient time series data and the application of non-parametric statistical tools for comparison constitute the main limitations of the current study. However, irrespective of our 
limited data, the employed methodology, namely the use of the panel model and the bootstrap process, has been demonstrated as a useful tool to interpret and evaluate EC performance at the national and regional level. Lastly, the findings of this work corroborate that the entrepreneurial process is not only a function of individual skill, knowledge, and opportunity-seeking abilities, but also highly dependent on the entrepreneurial environment fostered within the universityindustry-government complex, the knowledge transfer rate between universities and industry, as well as the state of government policies to support IPR laws, which can contribute to protect and incentivise the entrepreneurial process.

\section{NOTES}

1. PerCa $=$ Perceived capabilities of the entrepreneur (percentage of 18-64 population who believe they have the required skills and knowledge to start a business).

2. $\quad F e f R a=$ Fear of failure (percentage of 18-64 population perceiving good opportunities to start a business who indicate that fear of failure would prevent them from setting up a business).

3. EnGC $=$ Entrepreneurship as a good career choice (percentage of 18-64 population who agree with the statement that in their country, most people consider starting a business as a desirable career choice).

4. $\mathrm{PO}=$ Perceived opportunity (percentage of 18-64 population who see good opportunities to start a firm in the area where they live).

5. $\mathrm{KT}=$ Knowledge transfer (knowledge transfer is highly developed between companies and universities; updated: MAY 2012, IMD WCY executive survey based on an index from 0 to 10 ).

6. $\quad \mathrm{IPR}=$ Intellectual property rights (intellectual property rights are adequately enforced; updated: MAY 2012, IMD WCY executive survey based on an index from 0 to 10).

7. $\mathrm{UE}=$ University education of the entrepreneurs (university education meets the needs of a competitive economy; updated: MAY 2012, IMD WCY executive survey based on an index from 0 to 10 ).

\section{REFERENCES}

Afzal, M.N.I. (2013). Are science valleys and clusters panacea for a knowledge economy? An investigation on Regional Innovation System (RIS): Concepts, theory and empirical analysis. Asian Research Policy (ARP), 4(2), 114-125.

Afzal, M.N.I., \& Lawrey, R. (2014). Measuring the importance and efficiency of research and development expenditures in the transformation of knowledge-based economies: A case study of the ASEAN region. International Journal of AsiaPacific Studies, 10(1), 33-47. 
Afzal, M.N.I., Mansur, K.B.H.M., \& Sulong, R.S. (2017). An empirical investigation of triple helix and national innovation system dynamics in ASEAN-5 economies. Asian Journal of Innovation and Policy, 6(3), 313-331. https://oi.org/10.7545/ ajip.2017.6.3.313

Aghion, P., Howitt, P., \& Mayer-Foulkes, D. (2005). The effect of financial development on convergence: Theory and evidence. Quarterly Journal of Economics, 120(1), 173-222. https://doi.org/10.1162/0033553053327515

Antonioli, D., Nicolli, F., Ramaciotti, L., \& Rizzo, U. (2016). The effect of intrinsic and extrinsic motivations on academics' entrepreneurial intention. Administrative Sciences, 6(4), 15-25. https://doi.org/10.3390/admsci6040015

Arenius, P., \& Minniti, M. (2005). Perceptual variables and nascent entrepreneurship. Small Business Economics, 24(3), 233-247. https://doi.org/10.1007/s11187-0051984-X

ASEAN Secretariat (2014). ASEAN State of Education Report 2013. Jakarta, Indonesia: ASEAN Secretariat.

Audu, S.I., Otitolaiye, J.O., \& Ibitoye, S.J. (2013). A stochastic frontier approach to measurement of cost efficiency in small scale cassava production in Kogi State, Nigeria. European Scientific Journal, 9(9), 114-122.

Autio, E., Keeley, R.H., Klofsten, M., Parker, G.G.C, \& Hay, M. (2001). Entrepreneurial intent among students in Scandinavia and in the USA. Enterprise and Innovation Management Studies, 2(2), 145-160. https://doi.org/10.1080/14632440110094632

Bergmann, H., Mueller, S., \& Schrettle, T. (2014). The use of global entrepreneurship monitor data in academic research: A critical inventory and future potentials. International Journal of Entrepreneurial Venturing, 6(3), 242-276. https://doi. org/10.1504/IJEV.2014.064691

Cantu-Ortiz, F.J., Galeano, N., Mora-Castro, P., \& Fangmeyer, J. (2017). Spreading academic entrepreneurship: Made in Mexico. Business Horizons, 60(4), 541-550. https://doi.org/10.1016/j.bushor.2017.04.002

Capannelli, G. (2014). The ASEAN economy in the regional context: Opportunities, challenges, and policy options (No. 145). ADB Working Paper Series on Regional Economic Integration.

Chen, Y.Y., Schmidt, P., \& Wang, H.J. (2014). Consistent estimation of the fixed effects stochastic frontier model. Journal of Econometrics, 181(2), 65-76. https://doi. org/10.1016/j.jeconom.2013.05.009

Clarysse, B., Tartari, V., \& Salter, A. (2011). The impact of entrepreneurial capacity, experience and organizational support on academic entrepreneurship. Research Policy, 40(8), 1084-1093. https://doi.org/10.1016/j.respol.2011.05.010

Davidsson, P. (1995). Determinants of entrepreneurial intentions. Paper presented at the RENT IX Workshop in Entrepreneurship Research, Piacenza, Italy, 23-24 November.

D'este, P., Mahdi, S., \& Neely, A. (2009). Academic entrepreneurship: What are the factors shaping the capacity of academic researchers to identify and exploit entrepreneurial opportunities? Paper presented at the Summer Conference on CBS - Copenhagen Business School, Denmark, 17-19 June. 
Druilhe, C., \& Garnsey, E. (2004). Do academic spin-outs differ and does it matter? The Journal of Technology Transfer, 29(3), 269-285. https://doi.org/10.1023/ B:JOTT.0000034123.26133.97

Etzkowitz, H., Webster, A., Gebhardt, C., \& Terra, B.R.C.(2000). The future of the university and the university of the future: Evolution of ivory tower to entrepreneurial paradigm. Research Policy, 29(2), 313-330. https://doi.org/10.1016/S00487333(99)00069-4

Giuri, P., Grimaldi, R., \& Villani, E. (2014). Supporting academic entrepreneurship: Crosscountry evidence in Europe. Journal of Industrial and Business Economics, 41(4), 180-200. https://doi.org/10.3280/POLI2014-004010

Hallam, C., Novick, D., Gilbert, D.J., Frankwick, G.L., \& Zanella, G. (2017). Academic entrepreneurship and the entrepreneurial ecosystem: The UT transform project. Academy of Entrepreneurship Journal, 23(1), 77-90.

Hamidon, I.N., Suhaimie, M.H., Mat Yunoh, M.N., \& Hashim, H. (2017). Entrepreneurial intention among employees: An insight of entrepreneurial university in Malaysia. International Journal of Accounting, Finance and Business, 2(3), 01-13.

Haus, I., Steinmetz, H., Isidor, R., \& Kabst, R. (2013). Gender effects and entrepreneurial intention: A metaanalytical structural equation model. International Journal of Gender and Entrepreneurship, 5(2), 130-156. https://doi.org/ $10.1108 / 17566261311328828$

IMF (International Monetary Fund). (April 2016). World economic outlook: Too slow for too long. Washington, DC: International Monetary Fund.

Intarakumnerd, P., \& Schiller, D. (2009). University-industry linkages in Thailand: Successes, failures, and lessons learned for other developing countries. Seoul Journal of Economics, 22(4), 551-560.

Ismail, N., Nor, M.J.M., \& Sidek, S. (2015). A framework for a successful research products commercialisation: A case of Malaysian academic researchers. Procedia - Social and Behavioral Sciences, 195(July), 283-292. https://doi.org/10.1016/j. sbspro.2015.06.163

Klofsten, M., \& Jones-Evans, D. (2000). Comparing academic entrepreneurship in Europe: The case of Sweden and Ireland. Small Business Economics, 14(4), 299-309. https://doi.org/10.1023/A:1008184601282

Krueger, N. (1993). The impact of prior entrepreneurial exposure on perceptions of new venture feasibility and desirability. Entrepreneurship: Theory and Practice, 18(1), 5-22. https://doi.org/10.1177/104225879301800101

Light, I., \& Dana, L.P. (2013). Boundaries of social capital in entrepreneurship. Entrepreneurship Theory and Practice, 37(3), 603-624. https://doi.org/10.1111/ etap. 12016

Liñán, F., \& Chen, Y.W. (2009). Development and cross-cultural application of a specific instrument to measure entrepreneurial intentions. Entrepreneurship: Theory and Practice, 33(3), 593-617. https://doi.org/10.1111/j.1540-6520.2009.00318.x

Lockett, A., \& Wright, M. (2005). Resources, capabilities, risk capital and the creation of university spin-out companies. Research Policy, 34(7), 1043-1057. https://doi. org/10.1016/j.respol.2005.05.006 
Miranda, F.J., Chamorro-Mera, A., \& Rubio, S. (2017). Academic entrepreneurship in Spanish universities: An analysis of the determinants of entrepreneurial intention. European Research on Management and Business Economics, 23(2), 113-122. https://doi.org/10.1016/j.iedeen.2017.01.001

Nazaryeva, K. (2015). Academic entrepreneurship in the context of a technology transfer office: A case from Brazil. Master's dissertation, University of Oslo.

Noguera, M., Alvarez, C., \& Urbano, D. (2013). Socio-cultural factors and female entrepreneurship. International Entrepreneurship and Management Journal, 9(2), 183-197. https://doi.org/10.1007/s11365-013-0251-x

Nyström, K. (2008). The institutions of economic freedom and entrepreneurship: Evidence from panel data. Public Choice, 136(3-4), 269-282. https://doi.org/10.1007/ s11127-008-9295-9

Othman, N., \& Othman, S.H. (2017). The perceptions of public university students of entrepreneurship education in Malaysia. International Business Management, 11(4), 865-873.

Penrose, E.T. (1959). The theory of the growth of the firm. New York: Wiley.

Politis, D., \& Gabrielsson, J. (2009). Entrepreneurs' attitudes towards failure: An experiential learning approach. International Journal of Entrepreneurial Behavior \& Research, 15(4), 364-383. https://doi.org/10.1108/13552550910967921

Ramli, M.F., \& Senin, A.A. (2015). Success factors to reduce orientation and resourcesrelated barriers in university-industry R\&D collaboration particularly during development research stages. Procedia - Social and Behavioral Sciences, 172(January), 375-382. https://doi.org/10.1016/j.sbspro.2015.01.383

Rashed, F., Deluyi, A.H.M., \& Daud, K. (2015). Developing a mathematical model of entrepreneurship based on transformational leadership behavior. Jurnal Teknologi, 72(5), 125-131. https://doi.org/10.11113/jt.v72.3952

Razak, A.A., \& Saad, M. (2007). The role of universities in the evolution of the triple helix culture of innovation network: The case of Malaysia. International Journal of Technology Management \& Sustainable Development, 6(3), 211-225. https://doi. org/10.1386/ijtm.6.3.211_1

Schumpeter, J.R. (1942). Capitalism, socialism and democracy. New York: Harper \& Row.

Scippacercola, S., \& D'Ambra, L. (2014). Estimating the relative efficiency of secondary schools by stochastic frontier analysis. Procedia Economics and Finance, 17(2014), 79-88. https://doi.org/10.1016/S2212-5671(14)00881-8

Šebjan, U., Tominc, P., \& Boršič, D. (2016). Cross-country entrepreneurial intentions study: The Danube region perspective. Croatian Economic Survey, 18(2) 39-76. https://doi.org/10.15179/ces.18.2.2

Shane, S. (2000). Prior knowledge and the discovery of entrepreneurial opportunities. Organization Science, 11(4), 448-469. https://doi.org/10.1287/orsc.11.4.448. 14602

Siegel, D.S., \& Wright, M. (2015). Academic entrepreneurship: Time for a rethink? British Journal of Management, 26(4), 582-595. https://doi.org/10.1111/14678551.12116 
Siegel, D.S., Waldman, D.A., Atwater, L.E., \& Link, A.N. (2003). Commercial knowledge transfers from universities to firms: Improving the effectiveness of universityindustry collaboration. The Journal of High Technology Management Research, 14(1), 111-133. https://doi.org/10.1016/S1047-8310(03)00007-5

Simoes, A., Landry, D., Hidalgo, C., \& Teng, M. (2016). OEC: The observatory of economic complexity. Retrieved 3 February 2018 from https://atlas.media.mit. edu/en/

Sohn, D.W., \& Kenney, M. (2007). Universities, clusters, and innovation systems: The case of Seoul, Korea. World Development, 35(6), 991-1004. https://doi.org/10.1016/j. worlddev.2006.05.008

Sooampon, S., \& Igel, B. (2014). The individual's perceived environment as an antecedent of academic entrepreneurship: Multiple case studies of Thai university researchers. Journal of Enterprising Culture, 22(01), 57-90. https://doi.org/10.1142/ S0218495814500034

Thomas, A., \& Carl, D. (eds.). (2001). Korea and the knowledge-based economy: Making the transition. South Korea: OECD Publishing.

Tofighi, S., Teymourzadeh, E., \& Ghanizadeh, G. (2017). Academic entrepreneurship in a medical university: A system dynamics approach. International Review, (2017, No. 1-2), 58-72. https://doi.org/10.5937/intrev1702058T

Venkataraman, S. (1997). The distinctive domain of entrepreneurship research. Advances in Entrepreneurship, Firm Emergence and Growth, 3(1), 119-138.

Walker, J.K., Jeger, M., \& Kopecki, D. (2013). The role of perceived abilities, subjective norm, and intentions. Journal of Entrepreneurship, 22(2), 181-202. https://doi. org/10.1177/0971355713490621

Wilson, F., Kickul, J., \& Marlino, D. (2007). Gender, entrepreneurial self-efficacy, and entrepreneurial career intentions: Implications for entrepreneurship education. Entrepreneurship: Theory and Practice, 31(3), 387-406. https://doi.org/10.1111/ j.1540-6520.2007.00179.x

Wong, C.Y., \& Goh, K.L. (2010). Modelling the behaviour of science and technology: Self-propagating growth in the diffusion process. Scientometrics, 84(3), 669-686. https://doi.org/10.1007/s11192-010-0220-x

Wong, P.K., Ho, Y.P., \& Singh, A. (2007). Towards an “entrepreneurial university” model to support knowledge-based economic development: The case of the National University of Singapore. World Development, 35(6), 941-958. https://doi.org/ 10.1016/j.worlddev.2006.05.007

Woo, S., Jang, P., \& Kim, Y. (2015). Effects of intellectual property rights and patented knowledge in innovation and industry value added: A multinational empirical analysis of different industries. Technovation, 43-44(September-October), 4963. https://doi.org/10.1016/j.technovation.2015.03.003

Wright, M. (2007). Academic entrepreneurship in Europe. London: Edward Elgar Publishing. https://doi.org/10.4337/9781847205575

$\mathrm{Xu}$, L. \& Tian, M. (2017). Parametric bootstrap inferences for panel data models. Communications in Statistics - Theory and Methods, 46(11), 5579-5594. https://doi.org/10.1080/03610926.2015.1105981 